\title{
Comprehensive Study on Biochar and its Effect on Soil Properties: A Review
}

\author{
A. Karthik ${ }^{1}$, Syed Abul Hassan Hussainy ${ }^{2 *}$ and M. Rajasekar ${ }^{3}$ \\ ${ }^{1}$ Central Institute for Cotton Research, Regional Station, Coimbatore - 641 003, India \\ ${ }^{2}$ Department of Agronomy, AC \& RI, Madurai - 625 104, India \\ ${ }^{3}$ Department of Agronomy, AC \& RI, Kudumiyanmalai, Pudukottai-622 104, India
}

*Corresponding author

\begin{abstract}
A B S T R A C T
Soils in India are declining in fertility status due to higher usage of synthetic fertilizers and mono-cropping practices. To maintain the sustainability of soil and better crop production, it is essential to retain physical, chemical and biological properties of the soil through optimum level of organic matter. This article deals on the literature related to biochar, its production and characterization and its effect on soil application. The biochar application to the soil is a novel technique to improve soil fertility and thereby the soil productivity. The excess crop residues accumulated in the field after harvest can be utilized for biochar preparation along with inorganic fertilizers. Any waste material like wood chips, crop residues such as straw, husk, stover, trash and organic waste from industries can be effectively utilized for the production of biochar. Biochar from prosopis, cotton and maize which are available on-site have shown to significantly improve the soil physico-chemical parameters and thereby can be used as an alternative to other slow degrading bulky organic manures. The major cause for improvement in soil fertility on application of biochar is due to addition of organic carbon, slow release of applied nutrients through chelation effect, improved water holding capacity and porosity of soil.
\end{abstract}

\section{Introduction}

The use of biochar, a porous, carbon rich material prepared from crop biomass through pyrolysis process could help in saving nutrient losses sustainably. The crop biomasses are subjected to thermo-chemical conversion under absence of oxygen with a temperature range $350^{\circ} \mathrm{C}$ to $500^{\circ} \mathrm{C}$.
The properties of biochar material produced through pyrolysis process depend upon the biomass used and also the temperature involved in preparation. Biochar application into the soil as an amendment improves soil physical, chemical and biological properties and thereby solves many of the soil related issues (Singh et al., 2012). Biochar is persistent in soils and its beneficial effects are 
longer lasting compared to other forms of organic matter. The unique nature of the biochar is that it retains most of the applied nutrients and makes them available to growing plants than other organic matter like on farm common leaf litter, compost or manures (Schulz et al., 2013).

The excess crop residues accumulated in the field after harvest can be effectively utilized for biochar preparation. The different types of biochar in combination with organic and inorganic fertilizers significantly improve soil tilth (Glaser et al., 2002), crop productivity (Graber et al., 2010) and nutrient availability (Lehmann et al., 2006; Silber et al., 2010). The increase in crop yield in biochar incorporated soil was due to higher nutrient availability and concentrations of basic cations (Uzoma et al., 2011).

In acid soils, liming effect of biochar enhances soil microbial diversity and its function, together with increasing cation exchange capacity and crop water availability (Anderson et al., 2011). Sandy soils which have smaller surface area compared to other soil types, when applied with biochar improve the water holding capacity. Porous nature and higher surface area of biochar leads to retention of higher amount of soil moisture available for crop uptake (Fang et al., 2014).

The biochar has major benefits like improving soil fertility, structure, water holding capacity, organic carbon content, increased biological activity, thereby, improved crop yield in a sustainable manner (Masto et al., 2013). It also serves as better alternate for other organic manures as it does similar work as that of FYM and other composts. According to Zhang et al., (2013) biochar is generated by thermo-chemical conversion of biomass under oxygen-limited conditions. Shackley et al., (2012) defined "biochar is a carbon and energy-rich porous material produced through slow pyrolysis of biomass, which has been proposed as a way of storing carbon in soils for the long-term''. Xu et al., (2013) reported that any organic residues can be converted into biochar through pyrolysis.

\section{Raw materials for biochar production}

Cantrell et al., (2012) suggested that different types of materials like bark of the tree, wood chip and pellets, crop residues such as straw, rice husk, maize stover, cotton stalk and sugarcane trash and organic waste of paper sludge, sugarcane baggase, chicken litter, dairy manure and sewage sludge can be effectively utilized for the production of biochar.

Other agricultural residues like corn cob, corn stalk, wheat straw, rice straw, stalk of pearl millet, cotton, mustard, soybean and sugar beet crop residues and agro-industrial waste like paper mill waste, Jatropha husk, coffee husk, coconut shell and cocoa pod (Prabha et al., 2015; Purakayastha et al., 2015) also can be effectively utilized.

Venkateswarlu et al., (2012) observed that crop residues of maize, castor, cotton and pigeonpea, glyiricidia twig, eucalyptus bark, pongamia shell, eucalyptus twig and leucaena twig from rainfed areas are burnt in the field as farmers are facing difficulties in disposing these residues and suggested that these can be effectively utilized for biochar production.

\section{Biochar recovery}

Venkateswarlu et al., (2012) used pine needles, maize stalk and five weed biomasses for preparation of biochar and found that biochar recovery was higher in pine needles (47.72 per cent) and lowest recovery was recorded in setaria (23.23 per cent). Hernandez-Mena et al., (2014) inferred that reduction in biochar output with the increase 
in reaction temperature during preparation of bamboo biochar. At $300^{\circ} \mathrm{C}$, the biochar recovery was 60 per cent and at $600^{\circ} \mathrm{C}$ the biochar output was 30 per cent only.

Kamara et al., (2015) opined that biochar recovery from the raw rice straw was on the average of 29.7 per cent with an ash content of 34.2 per cent. The biochar produced from rice straw recorded low bulk density (0.75), higher $\mathrm{pH}$ (9.3) and phosphorus (738 mg $\mathrm{P}$ $\mathrm{kg}^{-1}$ biochar).

Pandian et al., (2016) concluded that the biochar conversion efficiency for prosopis was highest (45-52 per cent) followed by cotton stalk biochar (38-46 per cent), redgram stalk biochar (36-39 per cent), while maize stalk biochar recorded the lowest conversion efficiency of 32-35 per cent. The variations in recovery of biochar are mainly due to nature of the materials and pyrolysis temperature followed during the preparation.

Biochar yield of the crop residues varied from 20-25 per cent by weight. Shalini et al., (2017) observed maximum biochar yield of 27.5 per cent by weight from Coccus nucifera compared to Prosopis glandulosa hard wood biochar (24.8 per cent). The recovery of biochar mainly depends on cellulose and lignin content in the biomass. Tan et al., (2017) pointed out that at $600^{\circ} \mathrm{C}$ pyrolysis temperature, the biochar output of grass stalk was 16.1 per cent by weight whereas rape seed biomass recorded lower biochar yield of 8.5 per cent by weight.

\section{Biochar properties}

According to Lehmann (2007), biochar is primarily composed of condensed aromatic carbon ring and has higher surface area. Naeem et al., (2014) and Dume et al., (2015) indicated that quality and elemental compositions of the biochar mainly depend on production conditions specifically pyrolysis temperature and time duration for the process.

\section{Physical properties of biochar}

\section{Porosity}

$\mathrm{Yu}$ et al., (2009) suggested that biochar influence soil water holding and adsorption capacity through its porous structure. Nutrient retention ability of the biochar mainly depends on porosity and surface area which binds cations and anions on its surface (Chan et al., (2008). Lehmann and Joseph and Lehmann (2009) inferred that the porosity of biochar determined its surface area, labile pore size distribution viz. nano pores $(<0.9$ $\mathrm{nm})$, micro pores $(<2 \mathrm{~nm})$ and macro pores $(>50 \mathrm{~nm}$ ). Biochar produced at intermediate temperatures of $450^{\circ} \mathrm{C}$ to $750^{\circ} \mathrm{C}$, had higher surface area of 200 to $>500 \mathrm{~m}^{2} \mathrm{~g}^{-1}$ and was highly porous in nature. Further, they concluded that the large surface area of the biochar increased the porosity and had positive effect on soil. Macro pores present in the soils promotes aeration and provided shelter space for microbes. Atkinson et al., (2010) opined that micro pores were involved in molecule adsorption and transport.

Angin (2013) stated that the water holding ability and adsorptive capacity of biochar in soil was depends on macro porous structure of biochar. According to Rogovska et al., (2014) biochar exhibit wide range of porosity and bulk density depending on source of biomass used and temperature maintained during pyrolysis process.

Bird et al., (2011) indicated that porosity of the biochar increased with increase in pyrolysis temperature. Wang and Liu (2015) reported that leaching of nitrogen from the soil was inhibited in biochar added soil due to porosity and large surface area of applied material. 
The adsorption ability of biochar mainly depends on pore structure and pore size.

\section{Surface area}

Day et al., (2005) recorded increase in surface area of biochar from $120 \mathrm{~m}^{2} \mathrm{~g}^{-1}$ at $400^{\circ} \mathrm{C}$ to $460 \mathrm{~m}^{2} \mathrm{~g}^{-1}$ at $900^{\circ} \mathrm{C}$ due to increase in production temperature. This implied that biochar derived at lower temperature has the property to release fertilizer nutrients in slow manner. Chan et al., (2008) observed that biochar derived from softwood had lower surface area and biochar from hardwood had higher surface area. The surface area of biochar prepared from various materials ranged from 200 to $300 \mathrm{~m}^{2} \mathrm{~g}^{-1}$ and biochar produced at higher temperature had high surface area of more than $400 \mathrm{~m}^{2} \mathrm{~g}^{-1}$.

Schimmelpfennig and Glaser (2012) found that porous structure of biochar facilitate lower bulk density and results in higher specific surface area ranging from $50-900$ $\mathrm{m}^{2} \mathrm{~g}^{-1}$. Clough et al., (2013) opined that biochar serves as habitat for beneficial microorganisms for its multiplication due to its larger surface area and more porous structure. Tan et al., (2017) concluded that the specific surface area of biochar is directly related with pyrolysis temperature and it was $0.16 \mathrm{~m}^{2} \mathrm{~g}^{-1}$ at $300^{\circ} \mathrm{C}$ and $110 \mathrm{~m}^{2} \mathrm{~g}^{-1}$ at $400{ }^{\circ} \mathrm{C}$. The specific surface area increases rapidly with increase in temperature from $300{ }^{\circ} \mathrm{C}$ to $500{ }^{\circ} \mathrm{C}$ and slow rate of increase in surface area was observed above $500{ }^{\circ} \mathrm{C}$.

\section{Water holding capacity}

Wang and Liu (2015) inferred that biochar produced different hard wood materials had good water holding capacity and maintained 72-86 per cent of saturation under free water flow conditions. Biochar from grass substrates showed slightly better water holding ability than the wood biochar.
Karunakaran (2017) stated that rice husk biochar was more compact with higher ash content, more number of pores and thereby higher water holding capacity than coconut shell biochar.

\section{Chemical properties of biochar}

\section{Organic carbon}

Biochar derived from the wood materials recorded more carbon and low ash, nutrient and cation exchange capacity than biochar derived from manures (Singh et al., 2010). Liang et al., (2010) indicated that it can be directly applied to different crops as a slow release fertilizer to improve soil fertility and build soil carbon. An experiment conducted by Keiluweit et al., (2010) revealed that the pyrolysis temperature of $550^{\circ} \mathrm{C}$ favours higher recovery of carbon and several nutrients like $\mathrm{N}, \mathrm{K}$, and $\mathrm{S}$ that are lost at higher temperatures. Incorporation of biochar into the soil results in the improvement soil organic carbon content as it contains higher organic carbon, resulting in mitigation of greenhouse gas emissions. According to Jha et al., (2010) the total carbon content in different biochar materials ranged from 33.0 per cent to 82.4 per cent.

Wang and Gao (2015) reported that the organic carbon content was $564 \mathrm{~g} \mathrm{~kg}^{-1}$ at the temperature of $300^{\circ} \mathrm{C}$ and it decreased by 28.03 per cent when temperature was increased to $450^{\circ} \mathrm{C}$ and further it declined by 54.02 per cent at $600^{\circ} \mathrm{C}$. This indicates that organic carbon decreases with increase in reaction temperature. Yulduzkhon (2014) observed that the apple-wood biochar had high carbon content ( 75 per cent) and low ash content (11.8 per cent) due to low pyrolysis temperature. Dume et al., (2015) found that when biochar was produced in the temperature range from 350 to $500^{\circ} \mathrm{C}$, organic carbon content was increased from 13.98 to 
20.57 per cent in coffee husk biochar and 16.45 to 26.91 per cent in corn cob biochar.

Zheng et al., (2018) inferred that application of biochar as nitrogenous fertilizer is less effective as it contains higher carbon content than nitrogen. The major element present in biochar is carbon (70-80 per cent by weight) with significantly lower nitrogen content $(<3$ per cent by weight). Mandal et al., (2015) concluded that maximum total organic carbon content was recorded in biochar from Avena fatua (56.2 per cent) followed by Setaria (55.2 per cent), pine needles (54.6 per cent) and Gynura (53.9 per cent). Laghari et al., (2016) opined that rice straw biochar had high carbon content of $871 \mathrm{~g} \mathrm{~kg}^{-1}$ as against 440 and $391 \mathrm{~g}$ $\mathrm{kg}^{-1}$ from manure and sludge-derived biochar, respectively.

Pandian et al., (2016) evaluated organic carbon content in different biochar and recorded the value of $25-32 \mathrm{~g} \mathrm{~kg}^{-1}$ in prosopis biochar, 21-76 $\mathrm{g} \mathrm{kg}^{-1}$ in maize stalk biochar, 24-76 $\mathrm{g} \mathrm{kg}^{-1}$ in redgram stalk biochar and 17-69 $\mathrm{g} \mathrm{kg}^{-1}$ in cotton stalk biochar. Total carbon content of different source of biochar varied from 66 per cent to 89 per cent and it was mainly due to accrual of carbon through process of pyrolysis and carbon content of the crop residue. The biochar recovery rate depends on temperature and feedstock materials used for preparation and higher carbon content was observed during low pyrolysis temperature of $400-450^{\circ} \mathrm{C}$ (Shalini et al., 2017).

Hydrogen ion concentration (pH) and electrical conductivity (EC)

According to Chan et al., (2008) variation in $\mathrm{EC}, \mathrm{pH}$, nitrogen and phosphorus concentrations occurred with the pyrolysis temperature when biochar were produced from same feedstock of chicken manure. Chan and $\mathrm{Xu}$ (2009) reported that wider variation in the $\mathrm{pH}$ and nutrient composition of $\mathrm{N}, \mathrm{P}$ and $\mathrm{K}$ exist in the biochar produced from different organic materials. Yuan et al., (2011) observed that increase in pyrolysis temperature leads to hydrolysis of carbonates and bicarbonates of base cations such as $\mathrm{Ca}$, $\mathrm{Mg}, \mathrm{Na}$ and $\mathrm{K}$ and also separation of cations and organic anions from source materials resulting in higher $\mathrm{pH}$ of biochar. HernandezMena et al., (2014) revealed that biochar produced from apple wood at higher temperature of $400^{\circ} \mathrm{C}$ shown higher $\mathrm{pH}$ value of 8.67. Wang and Gao (2015) found that $\mathrm{pH}$ of the biochar increased with pyrolysis temperature and this might be due to the fact that higher biochar production temperature could increase the percent of alkaline cations of $\mathrm{Ca}, \mathrm{Mg}, \mathrm{K}$.

Laghari et al., (2016) pointed out that the increase in $\mathrm{pH}$ range of 6.35 to 9.08 was observed at pyrolysis temperature from 400 to $800{ }^{\circ} \mathrm{C}$. Pandian et al., (2016) inferred that the highest $\mathrm{pH}$ value of 9.4 to 10.8 and electrical conductivity of $0.83-1.25 \mathrm{dSm}^{-1}$ was recorded in prosopis biochar. Tan et al., (2017) opined that the biochar produced from rice straw has maximum $\mathrm{pH}$ of 10.6 , which is 11.2 per cent higher than that of bamboo biochar. Shalini et al., (2017) reported that $\mathrm{pH}$ value of different biochar varied from 9.64 to 9.90 and maximum was recorded in Prosopis glandulosa hard wood biochar which can be used for acid soil reclamation.

\section{Cation exchange capacity (CEC)}

Quality of biochar is decided by source of organic materials used for production, adsorption capacity and cation exchange capacity. Over a period of time, decrease in biochar adsorption capacity and increase in cation exchange capacity was noticed (Chan et al., 2008; McLaughlin, 2010). Lehmann et al., (2009) and Wu et al., (2012) revealed that biochar preparation temperature and 
feedstock material decides the CEC of biochar. Once biochar amended into the soil, CEC increases due to oxidization of the functional groups on the surface of biochar. According to Liang et al., (2010) biochar contain many functional groups of hydroxyl and carboxyl and these plays major role in improvement of cation exchange capacity.

Jiang et al., (2013) noted that cation exchange capacity of biochar mainly depends on its surface area, the existence of carboxyl functional groups, biomass materials and temperature during production process. Bera et al., (2014) found that the biochar produced from wheat and rice showed higher cation exchange capacity than the biochar produced from other materials.

Narzari et al., (2015) reported that the increase in CEC was significant with the increase in pyrolysis temperature and it was directly proportional to production temperature. Dume et al., (2015) observed that biochar produced from coffee husk and corn cob at $500^{\circ} \mathrm{C}$ recorded higher CEC and phosphorus concentration.

Study conducted by Kamara et al., (2015) revealed that the rice straw biochar recorded higher cation exchange capacity of $44.2 \mathrm{cmol}$ $\mathrm{kg}^{-1}$ and was also rich in exchangeable cation $\mathrm{K}(39.7 \mathrm{cmol} / \mathrm{kg})$ as compared to $\mathrm{Mg}$ and $\mathrm{Ca}$ $\left(5.8 \mathrm{cmol} \mathrm{kg}{ }^{-1}\right.$ and $\left.12.6 \mathrm{cmol} \mathrm{\textrm {kg } ^ { - 1 }}\right)$, respectively. The biochar produced from crop residues showed higher CEC $\left(56.9 \mathrm{cmol} \mathrm{kg}^{-1}\right)$ followed by manure-derived biochar (47.0 cmol kg-1). Laghari et al., (2016) inferred that the cations of $\mathrm{K}, \mathrm{Na}, \mathrm{Ca}, \mathrm{Mg}$, and $\mathrm{P}$ present in the source materials promote the formation of oxygen containing functional groups on the surface of biochar during pyrolysis process that results in higher CEC of the biochar.

Tan and Lin (2017) concluded that the variation in CEC of biochar is probably due to different source of materials used for the preparation of biochar under different pyrolysis temperature and also functional groups present on the surface of the biochar. CEC of biochar are generally in the range of 5 and $10 \mathrm{cmol} \mathrm{kg}^{-1}$.

\section{Prosopis biochar}

Shenbagavalli and Mahimairaja (2012) observed higher carbon content of $940 \mathrm{~g} \mathrm{~kg}^{-1}$ and $\mathrm{C}: \mathrm{N}$ ratio of 83.9 in prosopis biochar. It also contains higher amount of cellulose (36 per cent) than the hemicelluloses (31 per cent) and the lignin content (22 per cent). Manikandan and Subramanian (2013) indicated that the prosopis biochar contained 86.5 per cent carbon, 1.56 per cent nitrogen, 55:1 C:N ratio, $\mathrm{pH}$ of 9.16 and $\mathrm{EC}$ of 0.15 $\mathrm{dSm}^{-1}$. The bulk density, particle density and pore space percentage recorded in the prosopis biochar was $0.50,0.71 \mathrm{~g} \mathrm{cc}^{-1}$ and 30 per cent, respectively.

According to Gebremedhin et al., (2015) properties of prosopis biochar viz. $\mathrm{pH}$ was almost neutral (6.8) with electrical conductivity of $86 \mathrm{dSm}^{-1}$, organic carbon content of 3.46 per cent, total nitrogen of 0.44 per cent and total phosphorus of 0.07 per cent. CEC of biochar widely varied with range from 11.50 to $16.70 \mathrm{cmol} \mathrm{kg}$ and the maximum CEC was found in Prosopis glandulosa hard wood biochar $(16.70 \mathrm{cmol}$ $\mathrm{kg}^{-1}$ ).

Shalini et al., (2017) reported that the nutrient retention capacity of Prosopis glandulosa hard wood biochar is mainly dependent upon cation exchange capacity. Angalaeeswari and Kamaludeen (2017) observed that prosopis biochar has $\mathrm{pH}, \mathrm{EC}$ and $\mathrm{OC}$ of 8.73, $2.2 \mathrm{dSm}^{-}$ ${ }^{1}$ and 8.90 per cent, respectively. The physical properties like bulk density, particle density, moisture and ash content were 0.34, 0.23, 0.35 and 1.29 per cent, respectively. 


\section{Cotton biochar}

Decrease in yield of cotton stalk biochar from 37.35 per cent to 31.23 per cent and volatile matter content from 30.23 per cent to 13.76 per cent was noticed by Sun et al., (2014) when temperature increased from $400^{\circ} \mathrm{C}$ to $800^{\circ} \mathrm{C}$.

Venkatesh et al., (2013) concluded that the Total $\mathrm{C}$ and $\mathrm{N}$ content of the cotton biochar ranged between 592 to $719 \mathrm{~g} \mathrm{~kg}^{-1}$ and 10.3 to $17.4 \mathrm{~g} \mathrm{~kg}^{-1}$, respectively. Around 26 to 38 per cent of total carbon and 16 to 34 per cent of total nitrogen was recovered through production of biochar. Total nutrient contents of $\mathrm{P}, \mathrm{K}, \mathrm{Ca}, \mathrm{Mg}, \mathrm{Fe}, \mathrm{Cu}, \mathrm{Mn}$ and $\mathrm{Zn}$ in cotton biochar were higher as compared to cotton crop residue. The CEC of the cotton biochar ranged between 11.7 to $51.3 \mathrm{cmol} \mathrm{kg}^{-1}$. The biochar produced at $450-500^{\circ} \mathrm{C}$ possess maximum water holding capacity $\left(3.9 \mathrm{~g} \mathrm{~g}^{-1}\right.$ of dry biochar) and available water capacity (0.89 $\mathrm{g} \mathrm{g}^{-1}$ of dry biochar). Coumaravel et al., (2015) inferred that organic carbon content of cotton biochar was $174.6 \mathrm{~g} \mathrm{~kg}^{-1}$ and total $\mathrm{N}, \mathrm{P}$ and $\mathrm{K}$ contents were $0.322,0.0013$ and 1.038 per cent, respectively. The EC of cotton biochar was recorded in the range between 0.58-0.85 $\mathrm{dSm}^{-1}$ by Pandian et al., (2016). Zhang et al., (2016) opined that the cotton stalk had ash content of 13 per cent on weight basis and biochar recovery of 42 per cent compared to other materials (28-35 per cent). It was also observed that the cotton biochar recorded $44.0 \mathrm{dSm}^{-1}$ of EC, 24 per cent of organic carbon content, total carbon content of 55 per cent and high nitrogen content of 2.3 per cent.

\section{Maize biochar}

Venkateswarlu et al., (2012) revealed that the $\mathrm{pH}$ of biochar from maize (10.7) and pearl millet (10.6) was higher as compared to biochar prepared from wheat (8.8) and rice
(8.6). The maize biochar was low in bulk density, high in water holding capacity (45.6 per cent), low in carbon content (37 per cent) and rich in major (N, P and $\mathrm{K})$, secondary $(\mathrm{Ca}$ and $\mathrm{Mg}$ ) and micronutrient (Fe, $\mathrm{Mn}, \mathrm{Zn}$ and $\mathrm{Cu}$ ) content. Total carbon content was the highest in maize biochar (66 per cent) followed by biochar produced from pearl millet (64 per cent), wheat (64 per cent) and rice (60 per cent) (Bera et al., 2014).

Mandal et al., (2015) stated that phosphorus availability varied between the biochar and it was $3.32 \mathrm{mg} \mathrm{kg}^{-1}$ (Lantana biochar), $3.68 \mathrm{mg}$ $\mathrm{kg}^{-1}$ (Maize stalk biochar) as compared to $3.14 \mathrm{mg} \mathrm{kg}^{-1}$ in control plot. According to Pandian et al., (2016) the biochar obtained from maize stover recorded highest total $\mathrm{N}$ ( 0.45 per cent $)$ and total $\mathrm{P}(0.84$ per cent $)$ than prosopis biochar.

\section{Influence of biochar on soil properties}

\section{Physical properties}

\section{Soil porosity and surface area}

Liang et al., (2006) reported that biochar has greater surface area, negative surface charge and higher charge density resulting in better ability to adsorb cations than soil organic matter. Downie et al., (2009) observed that biochar when added as amendment, increased total soil specific surface area due to higher specific surface of biochar leads to improvement in soil water retention. Zwieten et al., (2010) found that distribution of pore size in biochar depends on structure of biomass and pyrolysis temperature. Woolf et al., (2010) inferred that addition of biochar influenced soil structure, texture, porosity, particle size distribution and density. This leads to improvement of air content, water holding capacity, microbial and nutritional condition of the soil within the rhizosphere of plant. 
Major et al., (2010) concluded that addition of biochar to soils increased surface area, distribution of pore size and lower the soil bulk density resulted in improvement of soil structure and porosity. Verheijen et al., (2010) revealed that increase or decrease of the overall porosity of soil mainly depend upon particle size, pore size distribution, connectivity, mechanical strength and interaction of biochar particles in the soil. Masulili et al., (2010) stated that addition of rice husk biochar at the rate of $10 \mathrm{tha}^{-1}$ and $15 \mathrm{t} \mathrm{ha}^{-1}$ increased total porosity of the soil.

Macro pores present have the ability to promote aeration and provide space for microbes. Micro pores were involved with molecule adsorption and transport (Atkinson et al., (2010). Herath et al., (2013) indicated that the porosity of soil has been increased by addition of biochar and this increase depends on the biochar and soil type. According to Mukherjee and Zimmerman (2013) porous nature of biochar increased porosity of applied soil. Wang et al., (2016) reported that addition of biochar on clay and poorly aggregated soils leads to less compacted soil and provide better aeration and increased moisture storage capacity.

\section{Bulk density of soil}

Liang et al., (2006) revealed that application of biochar to soil improves aeration due its porous nature and soil aggregation. Reduction in bulk density of soil was observed when biochar added to soil due to lower bulk density (Gundale and DeLuca, 2006).

Atkinson et al., (2010) found the reduction in bulk density of soil after addition of biochar and this in turn served as indicator for enhancement of soil structure and aeration. Mankasingh et al., (2011) inferred that application of $6.6 \mathrm{t} \mathrm{ha}^{-1}$ of cassia biochar increased the carbon content, organic matter and reduction in soil bulk density. Bulk density of biochar was lower compared to mineral particles, its addition at higher rate decrease bulk density of soil. (Lehmann et al., 2011; Alburquerque et al., 2014).

Zhang et al., (2012) concluded that consistent decrease in soil bulk density from 1.01 to 0.89 $\mathrm{g} \mathrm{cm}^{-3}$ compared control when biochar was added in soil @ $40 \mathrm{t} \mathrm{ha}^{-1}$. Githinji (2014) opined that significant decrease in bulk density was observed along with increasing rate of biochar application. Liu and Quek (2013) confirmed a decrease in soil bulk density and improvement in soil aggregate structure with biochar application, which ultimately increased total porosity in soil.

Glab et al., (2016) observed improvement in physical properties of sandy soil after addition of biochar. The soil bulk density decreased and total porosity increased by the increasing rate of biochar. Low bulk density of $1.36 \mathrm{~g}$ $\mathrm{cm}^{-3}$ and higher pore space (47.5 per cent) were recorded in redgram stalk biochar@5 t $\mathrm{ha}^{-1}$ applied plots over control (Pandian et al., 2016). Incorporation of biochar with low bulk density and stable organic carbon reduced the root penetration resistance and increased total soil porosity (Liu et al., 2017).

Venkatesh et al., (2018) reported positive effects of biochar incorporation on the soil health directly and indirectly. It changes soil physical properties like bulk density, soil structure, stability of soil, pore size distribution and density in correlation with aeration, water infiltration, and water holding capacity of the soil.

Soil chemical properties like nutrient retention, cation exchange capacity, $\mathrm{pH}$ and EC were changed positively. Apart from this it also reduced uptake of soil toxins and increased the population of beneficial soil microorganisms. 


\section{Water holding capacity}

Addition of biochar improves water, air and nutrient levels in soil. The surface of biochar when oxidized, becomes hydrophobic in nature resulting in increased water absorbance and water holding capacity. Returning crop residues in the form of biochar into soils is more conducive to increase the water content of soils than direct application of crop residues (Downie et al., 2009). The ability of biochar to hold higher quantity water facilitates its application on areas prone to drought. According to Chen et al., (2010) application of biochar produced from bagasse increased available soil moisture which facilitated for higher yield and sugar content in sugarcane.

Karhu et al., (2011) reported that biochar amended soil recorded an 11 per cent increase in water holding capacity and a profound effect on soil fertility through increased water retention. Sukartono et al., (2011) observed that water use efficiency (WUE) of maize in coconut shell biochar applied plot was 9.44 $\mathrm{kg} \mathrm{mm}^{-1}$ and for cattle dung biochar $9.24 \mathrm{~kg}$ $\mathrm{mm}^{-1}$. Both the biochar improved water use efficiency in sandy loam soils and increased maize production. Abel et al., (2013) stated that amendment of maize husk biochar influenced the soil properties and thereby increased total pore volume and water content up to 16.3 per cent.

Gururaj and Krishna (2016) pointed out that addition of biochar would be helpful to retain more amount water in soil. Biochar added soil recorded low water evaporation rate when compared to control. Pandian et al., (2016) found that biochar incorporated @ $5 \mathrm{t} \mathrm{ha}^{-1}$ reduced the bulk density of soil from 1.41 to $1.36 \mathrm{~g} \mathrm{~cm}^{-3}$ and increased the soil moisture by 2.5 per cent. Biochar incorporation increased soil moisture in sandy loam soil due to the higher surface area and porous nature of biochar and simultaneously enhanced the infiltration of rainwater.

\section{Chemical properties}

\section{Organic carbon}

Wang and Liu (2015) inferred that biochar prepared from wheat straw and applied to calcareous soils of China @ $20 \mathrm{t} \mathrm{ha}^{-1}$ increased soil organic carbon and total nitrogen by $25-54$ per cent and $4-12$ per cent, respectively, whereas it had no effect on soil $\mathrm{pH}$ and available nitrogen. Mandal et al., (2015) concluded that biochar produced from Gynura recorded highest increase in soil organic carbon (1.74 per cent), followed by biochar derived from weed species like Ageratum, Lantana and Setaria (1.70 per cent). Organic carbon content of the soil was increased with increasing application rate of biochar $\left(150,155,165\right.$ and $175 \mathrm{~g} \mathrm{~kg}^{-1}$ after the application of 2 per cent, 3 per cent, 5 per cent and 10 per cent biochar respectively) and control registered lower carbon of $146 \mathrm{~g} \mathrm{~kg}^{-1}$ (Kaur and Sharma, 2015).

Rafi et al., (2015) opined that application of biochar on an average increased total soil carbon in the range of 41 to 65 per cent. Maize stover and wheat straw biochar incorporated soils recorded highest total soil carbon compared to rice straw biochar treated soil. Study conducted by Coumaravel et al., (2015) revealed that the organic carbon content of the soil varied between $3.22 \mathrm{~g} \mathrm{~kg}^{-1}$ to $5.91 \mathrm{~g} \mathrm{~kg}^{-1}$ and application of NPK $\left(250: 75: 75 \mathrm{~kg} \mathrm{ha}^{-1}\right)+$ FYM @12.5 $\mathrm{t} \mathrm{ha}^{-1}+$ Biochar@15 t ha-1 + Azospirillum@2 kg $\mathrm{ha}^{-1}$ in maize recorded the highest organic carbon content (5.91 $\mathrm{g} \mathrm{kg}^{-1}$ ) than other treatments. Application of different sources of biochar had soil organic carbon (OC) content ranged between 4.4 and $4.8 \mathrm{~g} \mathrm{~kg}^{-1}$ and control had only $3.6 \mathrm{~g} \mathrm{~kg}^{-1}$ OC. The highest OC content $\left(4.8 \mathrm{~g} \mathrm{~kg}^{-1}\right)$ was noticed in maize 
stalk biochar and redgram stalk biochar @ $5 \mathrm{t}$ ha $^{-1}$ applied plots (Pandian et al., 2016). Rajagopal (2018) indicated that the carbon loss from biochar incubated soil was high during initial period of time and decreased latter and reaches constant value.

\section{Hydrogen ion concentration (pH) and electrical conductivity}

Zwieten et al., (2010) reported that biochar can be used to improve soil $\mathrm{pH}$ as it decreases exchangeable aluminium and hydrogen ions by adsorption through basic cations like potassium, calcium and magnesium present in the biochar. According to Galinato et al., (2011) biochar application had the ability to improve soil acidity by increasing $\mathrm{pH}$ for wheat cultivation from $\mathrm{pH}$ of 4.5 to 6.0 and thereby the yield was also increased from $3924 \mathrm{~kg} \mathrm{ha}^{-1}$ to $6219 \mathrm{~kg} \mathrm{ha}^{-1}$. Soil pH was significantly increased when biochar was applied due to domination of carbonates of alkali and alkaline earth metals in biochar. The $\mathrm{pH}$ value was highest in soils treated with $10 \mathrm{t} \mathrm{ha}^{-1}$ biochar and lowest value was recorded in control plot (Nigussie et al., 2012; Southavong et al., 2012).

Application of prosopis biochar with 10 per cent dose in pot culture study revealed that, soil $\mathrm{pH}$ was significantly increased to 10.9 compared to control (8.0). The increase in $\mathrm{pH}$ could be due to alkaline nature of biochar material added influenced $\mathrm{pH}$ of the soil (Kaur and Sharma, 2015). The surface of biochar contains oxygen active groups like $\mathrm{COOH}^{-}$or $\mathrm{OH}^{-}$and these react with metal cations and $\mathrm{H}^{+}$ions present in the soil resulted change in soil pH (Gan et al., 2015).

Liu and Zhang (2012) reported that increase in biochar application rate results in higher CEC that control soil salinization process in agricultural fields. The highest $\mathrm{pH}$ (6.33) and EC $\left(0.42 \mathrm{dSm}^{-1}\right)$ was recorded by the application of prosopis biochar @ $5 \mathrm{t} \mathrm{ha}^{-1}$ followed by cotton stalk biochar @ $5 \mathrm{t} \mathrm{ha}^{-1}$ (pH: 6.30 and EC: 0.35). The increase in soil $\mathrm{pH}$ in the biochar applied soil was primarily due to the alkaline $\mathrm{pH}$ (8.4-10.8) of biochar (Pandian et al., 2016). Biochar application in acidic soil results in increased soil $\mathrm{pH}$ that influences availability of macro and micro nutrients, which in turn increased the pod yield of groundnut. In acid soil, biochar application of $10 \mathrm{t} \mathrm{ha}^{-1}$ significantly increased soil $\mathrm{pH}$ from 4.62 to 5.87 and reduced the negative effect of $\mathrm{Al}$ (Wisnubroto et al., 2017). Song et al., (2014) observed that addition of cotton biochar at $5 \mathrm{t} \mathrm{ha}^{-1}$ does not have any impact on the $\mathrm{pH}$ of the alkaline soil.

In incubation study conducted by Wang and Gao (2015) reported that the soil $\mathrm{pH}$ showed an increase trend with the increased rate of maize straw biochar addition during the study period of 90 days. This confirmed that the biochar can be used as amendment for reclaiming acid soils due to its higher $\mathrm{pH}$.

\section{Cation exchange capacity}

The oxygen active groups present on surface of biochar are negatively charged and thus results higher CEC of biochar. CEC is an essential indicator of soil quality and soil amended with biochar increased soil CEC. A higher CEC of soil shows high capacity for nutrient fixation, which is highly essential for plant growth.

Viger et al., (2015) observed that the CEC plays major role in retaining and exchange of ions with its environment that includes microorganisms and plant roots. Biochar retain applied nutrients and provides to growing plants thereby minimizing the waste. Peng et al., (2011) inferred that incubation of rice straw derived biochar @ $2.4 \mathrm{t} \mathrm{ha}^{-1}$ for 11 days increased soil CEC from 4 to 17 per 
cent, reduction of aggregate stability from 1 to 17 per cent and improved the dry matter yield in maize crop.

Carvalho et al., (2014) concluded that biochar application increased CEC, organic carbon content, in turn improved soil structure and reduction soil $\mathrm{N}_{2} \mathrm{O}$ emission. In addition, it also improved available phosphorus, exchangeable cations and CEC in biochar treated soils (Kamara et al., 2015). Pandian et al., (2016) stated that application redgram stalk biochar@5 t ha ${ }^{-1}$ registered maximum CEC of $6.5 \mathrm{cmol} \mathrm{kg}^{-1}$. Biochar addition in the ratio of 1:100 increased soils CEC by 0.92 cmol kg-1 over control and CEC keeps on increased with the additional dose of biochar (Tan et al., 2017).

Study conducted by Alburquerque et al., (2014) showed that high CEC of the soil did not increase when biochar applied at different rates and the soil type used for conducting experiment was rich in sulphate $\left(\mathrm{SO}_{4}{ }^{-}\right)$and chloride $\left(\mathrm{Cl}^{-}\right)$anions.

\section{Biological properties}

\section{Influence on microbial population}

Rondon et al., (2007) reported that the addition biochar improved availability of boron and molybdenum that results in higher Biological Nitrogen Fixation (BNF) with common bean (Phaseolus vulgaris). Higher $\mathrm{pH}$ and less $\mathrm{N}$ availability along with increase in $\mathrm{K}, \mathrm{Ca}$ and $\mathrm{P}$ availability might also have contributed to nitrogen fixation. Bean yield increased by 46 per cent and biomass production by 39 per cent in biochar added plots.

Warnock et al., (2007) pointed out that biochar addition influenced soil microbial populations and soil biogeochemistry. Biochar with symbiotic mycorrhizal association in soil ecosystem benefited ecosystem restoration, carbon sequestration resulting in sustainable plant production. Biochar is an superior organic manure for increasing soil organic carbon, retention of water and shelter for microbes (Mankasingh et al., (2011).

Incorporation of biochar in the soil significantly increased the microbial efficiency, basal respiration and microbial biomass carbon (Steiner et al., 2008). Kolb et al., (2009) found that, biochar addition influenced the soil microbial biomass, activity and nutrient availability. The porous nature of biochar provides a safe habitat for many microorganisms such as mycorrhizal fungi, actinomycetes and bacteria. It helps to grow the microbial populations that benefits for plant growth (Lehmann et al., 2009). The pore space of biochar provided habitat for soil organism and protected from predators (Warnock et al., 2010).

Meng et al., (2013) claimed that addition of biochar, helps for the development and reproduction of microbes through supplying carbon, energy sources and mineral nutrition by retaining higher amount of moisture and improvement in soil quality. Lin et al., (2012) concluded that organic carbon and mineral nutrients are stored in the porous structure of biochar that influence soil microbial population and activity. The soil microbial biomass varied with the source of biochar used for preparation, soil texture and other soil ecosystem.

Anders et al., (2013) revealed that higher carbon and nutrient availability was increased due to biochar application or indirectly through activity of plant root thereby increase in soil microbial biomass. Abbas et al., (2017) opined that biochar addition increased the microbial population, specifically more number of bacterial colonies could be isolated 
and characterized which improved soil health and mobilized macro and micro nutrients to plants.

Incubation experiment conducted by Dong et al., (2013) with biochar produced at two different temperature of $350^{\circ} \mathrm{C}$ and $700^{\circ} \mathrm{C}$ showed that significant increase in microbial population in the biochar produced at $350^{\circ} \mathrm{C}$, while low biological activities in biochar prepared at $700^{\circ} \mathrm{C}$. Biochar added to the soil serves as store house for bacteria and AM fungi that mobilize soil nutrients for plant uptake (Fox et al., 2014). Graber et al., (2010) stated that biochar application increased the population of Pseudomonas, Mesorhizobium, Brevibacillus, Bacillus, and Trichoderma, which in turn improved conditions in the rhizosphere of the plant for better establishment of crop. Bhattachariya et al., (2017) recorded highest Microbial Biomass Carbon (MBC) was recorded with pine needle biochar@ $2.5 \mathrm{t} \mathrm{ha}^{-1}$ in soil after harvest of rice crop. The percentage increase in MBC was 147.2 per cent, 97.6 per cent and 65.7 per cent more over control,wheat residue @ 5.0 t $\mathrm{ha}^{-1}$ and lantana residue @ $2.5 \mathrm{t} \mathrm{ha}^{-1}$, respectively. The composition of soil microbial population was significantly changed by addition of biochar (Jiang et al., 2016).

According to Deb et al., (2016) biochar has the ability to increase ammonia and phosphates ions in soil and helped for the growth and multiplication of Phosphorus Solubilizing Microbes (PSM), which solublise and mobilize phosphorus in the soil for better uptake by plant roots. In phosphorus deficient soil, application of biochar along with PSM significantly increased crop yields. Wu et al., (2017) reported that increase in bacterial diversity was observed in biochar added soil and this was correlated with the quantity of biochar. Apart from this, addition of biochar in to the soil increased water holding capacity, enhanced microbial biomass and improvement in bacterial community structure resulted in reduction of nitrogen leaching.

Pandian et al., (2016) observed that the bacteria count was highest $\left(42 \times 10^{-6} \mathrm{CFU}\right)$ in redgram stalk biochar@ $5 \mathrm{t} \mathrm{ha}^{-1}$ applied plots followed by maize stalk biochar @ $2.5 \mathrm{t} \mathrm{ha}^{-1}$ $\left(41 \times 10^{-6} \mathrm{CFU}\right)$. In case of fungal population, higher number of colonies $\left(33 \times 10^{-3}\right)$ were recorded in coconut coir pith @ $\mathrm{t} \mathrm{ha}^{-1}$ followed by redgram stalk biochar @ $2.5 \mathrm{t} \mathrm{ha}$ ${ }^{1}\left(33 \times 10^{-3} \mathrm{CFU}\right)$. The actinomycetes were higher $\left(30 \times 10^{-4} \mathrm{CFU}\right)$ in cotton stalk biochar @ $5 \mathrm{t} \mathrm{ha}^{-1}$ incorporated plots. Tan et al., (2017) stated that pores present in the biochar facilitate growth, propagation and protection of microbes from unfavourable external environment. It also supply nutrients to microbes for their growth and multiplication.

\section{Enzyme activities}

Jin (2010) pointed out this the enzyme alkaline phosphatase was involved in the process of phosphorus mineralization followed by its utilization in soil and the increased rate of biochar ultimately increased the activities of soil alkaline phosphatases, while d-glucosidase activities decreased. Bailey et al., (2011) found that enzyme activities were influenced by interactions of biochar and type of enzymes present in the soil.

Awad et al., (2012) inferred that biochar amended soil promotes enzyme activities related to nitrogen and phosphorus translation and utilization and suppress soil carbon mineralization. Lal (2013) opined that addition of biochar showed significant influence on soil carbon that leads to increased enzyme activities. Chen et al., (2013) concluded that biochar incorporation increased soil $\mathrm{pH}$ resulting in higher activities 
of soil alkaline phosphatase. Rafi et al., (2015) stated that the application of biochar @ $5.0 \mathrm{t} \mathrm{ha}^{-1}$ along with 75 per cent RDF $+4 \mathrm{t}$ ha $^{-1}$ FYM increased oil microbial biomass carbon, dehydrogenase enzyme activity and soil organic carbon while reduction in exchangeable aluminium and exchangeable acidity.

The availability of phosphorus might be due to increased activity of alkaline phosphatase enzyme after biochar application (Xiao et al., 2016). Zhu et al., (2017) indicated that addition of wheat straw biochar increased urease activities due to higher absorption $\mathrm{p}$ nitrophenol by biochar breakdown.

Declining soil fertility is not a good indication for the increasing demands for agricultural production. Excess application of synthetic fertilizers along with cultivation of exhaustive crops under mono-cropping system resulted in destruction of soil physico-chemical properties along with soil health and quality. Biochar is a compressed charcoal-like substance produced from crop residues of agricultural fields or industrial by-products which are organic in nature produced through process of pyrolysis. Biochar not just improves the soil fertility but also aids in reduction of offsite pollution. Not just this, biochar increases the retention of applied nutrients further decreasing the leach-out of nutrients to the hydrosphere. In future, application of biochar needs to be addressed in order to facilitate sustainable agricultural practices along with onsite carbon sequestrations.

\section{References}

Abbas, T, M Rizwan, S Ali, M Zia-ur-Rehman, MF Qayyum, F Abbas, F Hannan, J Rinklebe, and YS Ok. 2017. "Effect of biochar on cadmium bioavailability and uptake in wheat (Triticum aestivum L.) grown in a soil with aged contamination."
Ecotoxicology and environmental safety 140:37-47.

Abel, S, A Peters, S Trinks, H Schonsky, M Facklam, and G Wessolek. 2013. "Impact of biochar and hydrochar addition on water retention and water repellency of sandy soil." Geoderma 202:183-191.

Alburquerque, JA, JM Calero, V Barrón, J Torrent, MC del Campillo, A Gallardo, and $\mathrm{R}$ Villar. 2014. "Effects of biochars produced from different feedstocks on soil properties and sunflower growth." Journal of Plant Nutrition and Soil Science 177 (1):16-25.

Anders, E, A Watzinger, F Rempt, B Kitzler, B Wimmer, F Zehetner, K Stahr, S Zechmeister-Boltenstern, and G Soja. 2013. "Biochar affects the structure rather than the total biomass of microbial communities in temperate soils." Agricultural and Food Science 22 (4):404-423.

Anderson, CR, LM Condron, TJ Clough, M Fiers, A Stewart, RA Hill, and RR Sherlock. 2011. "Biochar induced soil microbial community change: implications for biogeochemical cycling of carbon, nitrogen and phosphorus." Pedobiologia 54 (56):309-320.

Angalaeeswari, K, and S Kamaludeen. 2017. "Production and characterization of coconut shell and mesquite wood biochar." Int J Chem Stud 5:442-446.

Angin, D. 2013. "Effect of pyrolysis temperature and heating rate on biochar obtained from pyrolysis of safflower seed press cake." Bioresource technology 128:593-597.

Atkinson, CJ, JD Fitzgerald, and NA Hipps. 2010. "Potential mechanisms for achieving agricultural benefits from biochar application to temperate soils: a review." Plant and soil 337 (1-2):1-18.

Awad, YM, E Blagodatskaya, YS Ok, and Y Kuzyakov. 2012. "Effects of polyacrylamide, biopolymer, and biochar on decomposition of soil organic matter and plant residues as determined by $14 \mathrm{C}$ and enzyme activities." European Journal of Soil Biology 48:1-10.

Bailey, VL, SJ Fansler, JL Smith, and H Bolton Jr. 2011. "Reconciling apparent variability in effects of biochar amendment on soil 
enzyme activities by assay optimization." Soil biology and biochemistry 43 (2):296301.

Bera, T, T Purakayastha, and A Patra. 2014. "Spectral, chemical and physical characterisation of mustard stalk biochar as affected by temperature." Clay Research 33 (1):36-45.

Bhattachariya, S, R Chandra, MP Sharma, SK Sharma, and R Agnihotri. 2017. "Biochar and Crop Residue Amendments on Soil Microbial and Biochemical Properties." Proceedings of the National Academy of Sciences, India Section B: Biological Sciences 87 (3):975-983.

Bird, MI, CM Wurster, PH de Paula Silva, AM Bass, and R De Nys. 2011. "Algal biocharproduction and properties." Bioresource technology 102 (2):1886-1891.

Cantrell, KB, PG Hunt, M Uchimiya, JM Novak, and KS Ro. 2012. "Impact of pyrolysis temperature and manure source on physicochemical characteristics of biochar." Bioresource technology 107:419-428.

Carvalho, MdM, A Maia, BE Madari, L Bastiaans, PA Van Oort, AB Heinemann, MS da Silva, FA Petter, B Marimon Junior, and $\mathrm{H}$ Meinke. 2014. "Biochar increases plant-available water in a sandy loam soil under an aerobic rice crop system." Embrapa Arroz e Feijão-Artigo em periódico indexado (ALICE) 5 (1):939-952.

Chan, KY, L Van Zwieten, I Meszaros, A Downie, and S Joseph. 2008. "Agronomic values of greenwaste biochar as a soil amendment." Soil Research 45 (8):629-634.

Chan, KY, and Z Xu. 2009. "Biochar: nutrient properties and their enhancement." Biochar for environmental management: Science and technology 1:67-84.

Chen, W, W Zhang, and J Meng. 2013. "Advances and prospects in research of biochar utilization in agriculture." Scientia Agricultura Sinica 46 (16):3324-3333.

Chen, Y, Y Shinogi, and M Taira. 2010. "Influence of biochar use on sugarcane growth, soil parameters, and groundwater quality." Soil Research 48 (7):526-530.

Clough, T, L Condron, C Kammann, and C Müller. 2013. "A review of biochar and soil nitrogen dynamics." Agronomy 3 (2):275-
293.

Coumaravel, K, R Santhi, and S Maragatham. 2015. "Effect of biochar on yield and nutrient uptake by hybrid maize and on soil fertility." Indian Journal of Agricultural Research 49 (2):185-188.

Day, D, RJ Evans, JW Lee, and D Reicosky. 2005. "Economical CO2, SOx, and NOx capture from fossil-fuel utilization with combined renewable hydrogen production and large-scale carbon sequestration." Energy 30 (14):2558-2579.

Deb, D, M Kloft, J Lässig, and S Walsh. 2016. "Variable effects of biochar and $P$ solubilizing microbes on crop productivity in different soil conditions." Agroecology and Sustainable Food Systems 40 (2):145168.

Dong, D, M Yang, C Wang, H Wang, Y Li, J Luo, and $\mathrm{W}$ Wu. 2013. "Responses of methane emissions and rice yield to applications of biochar and straw in a paddy field." Journal of Soils and Sediments 13 (8):1450-1460.

Downie, A, A Crosky, and P Munroe. 2009. "Physical properties of biochar." Biochar for environmental management: Science and technology:13-32.

Dume, B, G Berecha, and S Tulu. 2015. "Characterization of biochar produced at different temperatures and its effect on acidic nitosol of Jimma, Southwest Ethiopia." International Journal of Soil Science 10 (2):63-73.

Fang, Y, B Singh, B Singh, and E Krull. 2014. "Biochar carbon stability in four contrasting soils." European Journal of Soil Science 65 (1):60-71.

Fox, A, W Kwapinski, BS Griffiths, and A Schmalenberger. 2014. "The role of sulfurand phosphorus-mobilizing bacteria in biochar-induced growth promotion of Lolium perenne." FEMS microbiology ecology 90 (1):78-91.

Galinato, SP, JK Yoder, and D Granatstein. 2011. "The economic value of biochar in crop production and carbon sequestration." Energy Policy 39 (10):6344-6350.

Gan, C, Y Liu, X Tan, S Wang, G Zeng, B Zheng, T Li, Z Jiang, and W Liu. 2015. "Effect of porous zinc-biochar nanocomposites on $\mathrm{Cr}$ (VI) adsorption from aqueous solution." 
Rsc Advances 5 (44):35107-35115.

Gebremedhin, G, H Bereket, B Daniel, and B Tesfaye. 2015. "Effect of biochar on yield and yield components of wheat and postharvest soil properties in Tigray, Ethiopia." Journal of Fertilizers \& Pesticides 6 (2):2-5.

Githinji, L. 2014. "Effect of biochar application rate on soil physical and hydraulic properties of a sandy loam." Archives of Agronomy and Soil Science 60 (4):457470.

Glab, T, J Palmowska, T Zaleski, and K Gondek. 2016. "Effect of biochar application on soil hydrological properties and physical quality of sandy soil." Geoderma 281:11-20.

Glaser, B, J Lehmann, and W Zech. 2002. "Ameliorating physical and chemical properties of highly weathered soils in the tropics with charcoal-a review." Biology and fertility of soils 35 (4):219-230.

Graber, ER, YM Harel, M Kolton, E Cytryn, A Silber, DR David, L Tsechansky, M Borenshtein, and Y Elad. 2010. "Biochar impact on development and productivity of pepper and tomato grown in fertigated soilless media." Plant and soil 337 (12):481-496.

Gundale, MJ, and TH DeLuca. 2006. "Temperature and source material influence ecological attributes of ponderosa pine and Douglas-fir charcoal." Forest ecology and management 231 (1-3):86-93.

Gururaj, SB, and B Krishna. 2016. "Water retention capacity of biochar blended soils." Journal of Chemical and Pharmaceutical Sciences 9 (3):1438-1441.

Herath, H, M Camps-Arbestain, and M Hedley. 2013. "Effect of biochar on soil physical properties in two contrasting soils: an Alfisol and an Andisol." Geoderma 209:188-197.

Hernandez-Mena, LE, AA Pécoraa, and AL Beraldob. 2014. "Slow pyrolysis of bamboo biomass: Analysis of biochar properties." Journal of Chemical Engineering 37:115120.

Jha, P, A Biswas, B Lakaria, and AS Rao. 2010. "Biochar in agriculture-prospects and related implications." Current Science 99 (9):1218-1225.

Jiang, J, L Zhang, X Wang, N Holm, K
Rajagopalan, F Chen, and S Ma. 2013. "Highly ordered macroporous woody biochar with ultra-high carbon content as supercapacitor electrodes." Electrochimica Acta 113:481-489.

Jiang, S, L Huang, TA Nguyen, YS Ok, V Rudolph, H Yang, and D Zhang. 2016. "Copper and zinc adsorption by softwood and hardwood biochars under elevated sulphate-induced salinity and acidic $\mathrm{pH}$ conditions." Chemosphere 142:64-71.

Jin, H. 2010. "Characterization of microbial life colonizing biochar and biochar-amended soils." Cornel University.

Joseph, S, and J Lehmann. 2009. Biochar for environmental management: science and technology: London, GB: Earthscan.

Kamara, A, HS Kamara, and MS Kamara. 2015. "Effect of rice straw biochar on soil quality and the early growth and biomass yield of two rice varieties." Agricultural Sciences 6 (08):798.

Karhu, K, T Mattila, I Bergström, and K Regina. 2011. "Biochar addition to agricultural soil increased $\mathrm{CH} 4$ uptake and water holding capacity-Results from a short-term pilot field study." Agriculture, ecosystems \& environment 140 (1-2):309-313.

Karunakaran, S. 2017. "Effect of biochar application on the chromium uptake of Canna indica L. from chromium spiked soil." Journal of Pharmacognosy and Phytochemistry 6 (4):146-152.

Kaur, V, and P Sharma. 2015. "Role of Biochar to Improve the Soil Conditions (A Study on Trifolium Alexandrinum)." International Journal of Science and Research 6 (6):510514.

Keiluweit, M, PS Nico, MG Johnson, and M Kleber. 2010. "Dynamic molecular structure of plant biomass-derived black carbon (biochar)." Environmental science \& technology 44 (4):1247-1253.

Kolb, SE, KJ Fermanich, and ME Dornbush. 2009. "Effect of charcoal quantity on microbial biomass and activity in temperate soils." Soil Science Society of America Journal 73 (4):1173-1181.

Laghari, M, Z Hu, MS Mirjat, B Xiao, AA Tagar, and $\mathrm{M} \mathrm{Hu}$. 2016. "Fast pyrolysis biochar from sawdust improves the quality of desert 
soils and enhances plant growth." Journal of the Science of Food and Agriculture 96 (1):199-206.

Lal, R. 2013. "Soil carbon management and climate change." Carbon Management 4 (4):439-462.

Lehmann, J. 2007. "A handful of carbon." Nature 447 (7141):143.

Lehmann, J, C Czimczik, D Laird, and S Sohi. 2009. "Stability of biochar in soil." Biochar for environmental management: Science and technology:183-206.

Lehmann, J, J Gaunt, and M Rondon. 2006. "Biochar sequestration in terrestrial ecosystemsa review." Mitigation and adaptation strategies for global change 11 (2):403-427.

Lehmann, J, MC Rillig, J Thies, CA Masiello, WC Hockaday, and D Crowley. 2011. "Biochar effects on soil biota-A Review." Soil biology and biochemistry 43 (9):18121836.

Liang, B, J Lehmann, D Solomon, J Kinyangi, J Grossman, B O'neill, J Skjemstad, J Thies, F Luizao, and J Petersen. 2006. "Black carbon increases cation exchange capacity in soils." Soil Science Society of America Journal 70 (5):1719-1730.

Liang, S, X Guo, N Feng, and Q Tian. 2010. "Isotherms, kinetics and thermodynamic studies of adsorption of $\mathrm{Cu} 2+$ from aqueous solutions by $\mathrm{Mg} 2+/ \mathrm{K}+$ type orange peel adsorbents." Journal of Hazardous Materials 174 (1-3):756-762.

Lin, Y, P Munroe, S Joseph, and R Henderson. 2012. "Migration of dissolved organic carbon in biochars and biochar-mineral complexes." Pesquisa Agropecuaria Brasileira 47 (5):677-686.

Liu, X-H, and X-C Zhang. 2012. "Effect of Biochar on $\mathrm{pH}$ of Alkaline Soils in the Loess Plateau: Results from Incubation Experiments." International Journal of Agriculture \& Biology 14 (5).

Liu, Z, B Dugan, CA Masiello, and HM Gonnermann. 2017. "Biochar particle size, shape, and porosity act together to influence soil water properties." Plos one 12 (6): $\mathrm{e} 0179079$.

Liu, Z, and A Quek. 2013. "Production of solid biochar fuel from waste biomass by hydrothermal carbonization." Fuel 103:943-
949.

Major, J, M Rondon, D Molina, SJ Riha, and J Lehmann. 2010. "Maize yield and nutrition during 4 years after biochar application to a Colombian savanna oxisol." Plant and soil 333 (1-2):117-128.

Mandal, S, B Verma, G Ramkrushna, R Singh, and D Rajkhowa. 2015. "Characterization of biochar obtained from weeds and its effect on soil properties of North Eastern Region of India." Journal of environmental biology 36 (2):499.

Manikandan, A, and K Subramanian. 2013. "Urea intercalated biochar-a slow release fertilizer production and characterisation." Indian Journal of Science and Technology 6 (12):5579-5584.

Mankasingh, U, P-C Choi, and V Ragnarsdottir. 2011. "Biochar application in a tropical, agricultural region: A plot scale study in Tamil Nadu, India." Applied Geochemistry 26:S218-S221.

Masto, RE, S Kumar, T Rout, P Sarkar, J George, and L Ram. 2013. "Biochar from water hyacinth (Eichornia crassipes) and its impact on soil biological activity." Catena 111:64-71.

Masulili, A, WH Utomo, and M Syechfani. 2010. "Rice husk biochar for rice based cropping system in acid soil 1 . The characteristics of rice husk biochar and its influence on the properties of acid sulfate soils and rice growth in West Kalimantan, Indonesia." Journal of Agricultural Science 2 (1):39.

McLaughlin, H. 2010. "Characterizing biochars prior to addition to soils-Version I." Alterna Biocarbon Inc 333:334.

Meng, J, L Wang, X Liu, J Wu, PC Brookes, and J Xu. 2013. "Physicochemical properties of biochar produced from aerobically composted swine manure and its potential use as an environmental amendment." Bioresource technology 142:641-646.

Mukherjee, A, and AR Zimmerman. 2013. "Organic carbon and nutrient release from a range of laboratory-produced biochars and biochar-soil mixtures." Geoderma 193:122130.

Naeem, MA, M Khalid, M Arshad, and R Ahmad. 2014. "Yield and nutrient composition of biochar produced from different feedstocks 
at varying pyrolytic temperatures." Pakistan Journal of Agricultural Sciences 51 (1):7582.

Narzari, R, N Bordoloi, RS Chutia, B Borkotoki, N Gogoi, A Bora, and R Kataki. 2015. "Biochar: An Overview on its production, properties and potential benefits." Biology, Biotechnology and Sustainable Development 1 (1):13-40.

Nigussie, A, E Kissi, $M$ Misganaw, and $G$ Ambaw. 2012. "Effect of biochar application on soil properties and nutrient uptake of lettuces (Lactuca sativa) grown in chromium polluted soils." AmericanEurasian Journal of Agriculture and Environmental Science 12 (3):369-376.

Pandian, K, P Subramaniayan, P Gnasekaran, and S Chitraputhirapillai. 2016. "Effect of biochar amendment on soil physical, chemical and biological properties and groundnut yield in rainfed Alfisol of semiarid tropics." Archives of Agronomy and Soil Science 62 (9):1293-1310.

Peng, X, L Ye, C Wang, H Zhou, and B Sun. 2011. "Temperature-and durationdependent rice straw-derived biochar: Characteristics and its effects on soil properties of an Ultisol in southern China." Soil and Tillage Research 112 (2):159-166.

Prabha, B, S Pugalendhi, and P Subramanian. 2015. "Design and development of semiindirect non-electric pyrolytic reactor for biochar production from farm waste." Indian Journal of Agricultural Sciences 85 (4):585-591.

Purakayastha, T, S Kumari, and H Pathak. 2015. "Characterisation, stability, and microbial effects of four biochars produced from crop residues." Geoderma 239:293-303.

Rafi, JM, A Rajashekar, M Srinivas, B Rao, R Prasad, and N Lingaiah. 2015. "Esterification of glycerol over a solid acid biochar catalyst derived from waste biomass." Rsc Advances 5 (55):4455044556.

Rajagopal, V. 2018. "Prospects of Biochar in Climate Change Mitigation in Indian Agriculture-An Analysis." International Journal of Agriculture Sciences, ISSN:0975-3710.

Rogovska, N, DA Laird, SJ Rathke, and DL
Karlen. 2014. "Biochar impact on Midwestern Mollisols and maize nutrient availability." Geoderma 230:340-347.

Rondon, MA, J Lehmann, J Ramírez, and M Hurtado. 2007. "Biological nitrogen fixation by common beans (Phaseolus vulgaris L.) increases with bio-char additions." Biology and fertility of soils 43 (6):699-708.

Schimmelpfennig, S, and B Glaser. 2012. "One step forward toward characterization: some important material properties to distinguish biochars." Journal of Environmental Quality 41 (4):1001-1013.

Schulz, H, G Dunst, and B Glaser. 2013. "Positive effects of composted biochar on plant growth and soil fertility." Agronomy for sustainable development 33 (4):817-827.

Shackley, S, S Carter, T Knowles, E Middelink, S Haefele, S Sohi, A Cross, and S Haszeldine. 2012. "Sustainable gasification-biochar systems? A case-study of rice-husk gasification in Cambodia, Part I: Context, chemical properties, environmental and health and safety issues." Energy Policy 42:49-58.

Shalini, R, S Pugalendhi, P Subramanian, and N Gopal. 2017. "Characteristic study on biochar production from biological substrates by slow pyrolysis for carbon sequestration." International Journal of Current Microbiology and Applied Sciences 6 (4):314-323.

Shenbagavalli, S, and S Mahimairaja. 2012. "Characterization and effect of biochar on nitrogen and carbon dynamics in soil." International journal of advanced biological research 2 (2):249-255.

Silber, A, I Levkovitch, and E Graber. 2010. "pHdependent mineral release and surface properties of cornstraw biochar: agronomic implications." Environmental science \& technology 44 (24):9318-9323.

Singh, BP, AL Cowie, and RJ Smernik. 2012. "Biochar carbon stability in a clayey soil as a function of feedstock and pyrolysis temperature." Environmental science \& technology 46 (21):11770-11778.

Singh, Y, SS Rao, and PL Regar. 2010. "Deficit irrigation and nitrogen effects on seed cotton yield, water productivity and yield 
response factor in shallow soils of semi-arid environment." Agricultural water management 97 (7):965-970.

Song, X, X Xue, D Chen, P He, and X Dai. 2014. "Application of biochar from sewage sludge to plant cultivation: Influence of pyrolysis temperature and biochar-to-soil ratio on yield and heavy metal accumulation." Chemosphere 109:213-220.

Southavong, S, T Preston, and N Man. 2012. "Effect of biochar and biodigester effluent on growth of water spinach (Ipomoea aquatic) and soil fertility." Livestock Research for Rural Development. Volume 24, Article 34.

Steiner, C, L Rademakers, and W Blum. 2008. "Biochar carbon sequestration." University of Georgia, Biorefining and Carbon Cycling Program, Athens, GA 30602.

Sukartono, UW, W Nugroho, and Z Kusuma. 2011. "Simple biochar production generated from cattle dung and coconut shell." J. Basic. Appl. Sci. Res 1 (10):1680-1685.

Sun, L, L Li, Z Chen, J Wang, and Z Xiong. 2014. "Combined effects of nitrogen deposition and biochar application on emissions of $\mathrm{N} 2 \mathrm{O}, \mathrm{CO} 2$ and $\mathrm{NH} 3$ from agricultural and forest soils." Soil science and plant nutrition 60 (2):254-265.

Tan, X-f, S-b Liu, Y-g Liu, Y-l Gu, G-m Zeng, Xj $\mathrm{Hu}, \mathrm{X}$ Wang, S-h Liu, and L-h Jiang. 2017. "Biochar as potential sustainable precursors for activated carbon production: multiple applications in environmental protection and energy storage." Bioresource technology 227:359-372.

Tan, Z, and C Lin. 2017. "Returning biochar to fields: A Review." Applied Soil Ecology 116:1-11.

Uzoma, K, M Inoue, H Andry, A Zahoor, and E Nishihara. 2011. "Influence of biochar application on sandy soil hydraulic properties and nutrient retention." Journal of Food, Agriculture \& Environment 9 (3/4 part 2):1137-1143.

Venkatesh, G, K Gopinath, K Sammi Reddy, B Sanjeeva Reddy, J Prasad, G Rajeshwar Rao, G Pratibha, RCG Srinivasarao Ch, M Prabhakar, and V Visha Kumari. 2018. "Biochar Production and its Use in Rainfed Agriculture: Experiences from CRIDA."
CRIDA-NICRA Research Bulletin 2 (2018):50.

Venkatesh, G, B Venkateswarlu, K Gopinath, C Srinivasrao, G Korwar, BS Reddy, J Prasad, M Grover, B Raju, and C Sasikala. 2013. "Biochar Production Technology for Conversion of Cotton Stalk Bioresidue into Biochar and its Characterization for Soil Amendment Qualities." Indian Journal of Dryland Agricultural Research and Development 28 (1):48-57.

Venkateswarlu, B, M Maheswari, M Srinivasa Rao, V Rao, C Srinivasa Rao, D Ramana, C Rama Rao, S Dixit, and A Singh. 2012. "National Initiative on Climate Resilient Agriculture (NICRA), Research Highlights (2010-12)." Central Research Institute for Dryland Agriculture, Hyderabad.

Verheijen, F, S Jeffery, A Bastos, M Van der Velde, and I Diafas. 2010. "Biochar application to soils." A critical scientific review of effects on soil properties, processes, and functions. EUR 24099:162.

Viger, M, RD Hancock, F Miglietta, and G Taylor. 2015. "More plant growth but less plant defence? First global gene expression data for plants grown in soil amended with biochar." Gcb Bioenergy 7 (4):658-672.

Wang, S, and B Gao. 2015. "Removal of arsenic by magnetic biochar prepared from pinewood and natural hematite." Bioresource technology 175:391-395.

Wang, S, B Gao, Y Li, AR Zimmerman, and X Cao. 2016. "Sorption of arsenic onto $\mathrm{Ni} / \mathrm{Fe}$ layered double hydroxide (LDH)-biochar composites." Rsc Advances 6 (22):1779217799.

Wang, Z, and G Liu. 2015. "Investigating the mechanisms of biochar's removal of lead from solution." Bioresource technology 177:308-317.

Warnock, DD, J Lehmann, TW Kuyper, and MC Rillig. 2007. "Mycorrhizal responses to biochar in soil-concepts and mechanisms." Plant and soil 300 (1-2):9-20.

Warnock, DD, DL Mummey, B McBride, J Major, J Lehmann, and MC Rillig. 2010. "Influences of non-herbaceous biochar on arbuscular mycorrhizal fungal abundances in roots and soils: results from growthchamber and field experiments." Applied 
Soil Ecology 46 (3):450-456.

Wisnubroto, E, W Utomo, and H Soelistyari. 2017. "Biochar as a carrier for nitrogen plant nutrition the release of nitrogen from biochar enriched with ammonium sulfate and nitrate acid." International Journal of Applied Engineering and Research 12 (6):1035-1042.

Woolf, D, JE Amonette, FA Street-Perrott, J Lehmann, and S Joseph. 2010. "Sustainable biochar to mitigate global climate change." Nature communications 1:56.

Wu, H, C Lai, G Zeng, J Liang, J Chen, J Xu, J Dai, X Li, J Liu, and M Chen. 2017. "The interactions of composting and biochar and their implications for soil amendment and pollution remediation: a review." Critical reviews in biotechnology 37 (6):754-764.

Wu, W, M Yang, Q Feng, K McGrouther, H Wang, H Lu, and Y Chen. 2012. "Chemical characterization of rice straw-derived biochar for soil amendment." Biomass and bioenergy 47:268-276.

Xiao, Q, L-x Zhu, Y-f Shen, and S-q Li. 2016. "Sensitivity of soil water retention and availability to biochar addition in rainfed semi-arid farmland during a three-year field experiment." Field Crops Research 196:284-293.

Xu, G, L Wei, J Sun, H Shao, and S Chang. 2013. "What is more important for enhancing nutrient bioavailability with biochar application into a sandy soil: Direct or indirect mechanism?" Ecological engineering 52:119-124.

Yu, X-Y, G-G Ying, and RS Kookana. 2009. "Reduced plant uptake of pesticides with biochar additions to soil." Chemosphere 76 (5):665-671.

Yuan, J-H, R-K Xu, W Qian, and R-H Wang. 2011. "Comparison of the ameliorating effects on an acidic ultisol between four crop straws and their biochars." Journal of Soils and Sediments 11 (5):741-750.

Yulduzkhon, A. 2014. "Biochar effects on fertility of saline and alkaline soils (navoiy region, uzbekistan)." Land Restoration Training Programme, Reykjavik, Iceland.

Zhang, D, M Yan, Y Niu, X Liu, L van Zwieten, D Chen, $\mathrm{R}$ Bian, $\mathrm{K}$ Cheng, $\mathrm{L} \mathrm{Li}$, and $\mathrm{S}$ Joseph. 2016. "Is current biochar research addressing global soil constraints for sustainable agriculture?" Agriculture, ecosystems \& environment 226:25-32.

Zhang, M, B Gao, Y Yao, Y Xue, and M Inyang. 2012. "Synthesis, characterization, and environmental implications of graphenecoated biochar." Science of the Total Environment 435:567-572.

Zhang, X, H Wang, L He, K Lu, A Sarmah, J Li, NS Bolan, J Pei, and H Huang. 2013. "Using biochar for remediation of soils contaminated with heavy metals and organic pollutants." Environmental Science and Pollution Research 20 (12):8472-8483.

Zheng, H, X Wang, L Chen, Z Wang, Y Xia, Y Zhang, H Wang, X Luo, and B Xing. 2018. "Enhanced growth of halophyte plants in biochar- amended coastal soil: roles of nutrient availability and rhizosphere microbial modulation." Plant, cell \& environment 41 (3):517-532.

Zhu, L-x, Q Xiao, H-y Cheng, B-j Shi, Y-f Shen, and S-q Li. 2017. "Seasonal dynamics of soil microbial activity after biochar addition in a dryland maize field in North-Western China." Ecological engineering 104:141149.

Zwieten, L, S Kimber, S Morris, K Chan, A Downie, J Rust, S Joseph, and A Cowie. 2010. "Effects of biochar from slow pyrolysis of papermill waste on agronomic performance and soil fertility." Plant and soil 327 (1-2):235-246.

\section{How to cite this article:}

Karthik. A., Syed Abul Hassan Hussainy and Rajasekar. M. 2020. Comprehensive Study on Biochar and its Effect on Soil Properties: A Review. Int.J.Curr.Microbiol.App.Sci. 9(05): 459477. doi: https://doi.org/10.20546/ijcmas.2020.905.052 